\title{
Effects of nano-silane on the physical and mechanical properties of oriented strand lumber (OSL)
}

\section{Hamid R. TAGHIYARI ${ }^{1}$}

Sadegh MALEKI ${ }^{2}$

Vahid HASSANI ${ }^{1}$

${ }^{1}$ Shahid Rajaee Teacher Training University Faculty of Civil Engineering

Wood Science and Technology Department Tehran

Iran

2 Tarbiat Modares University Faculty of Natural Resources Department of Wood Science and Technology Tehran

Iran

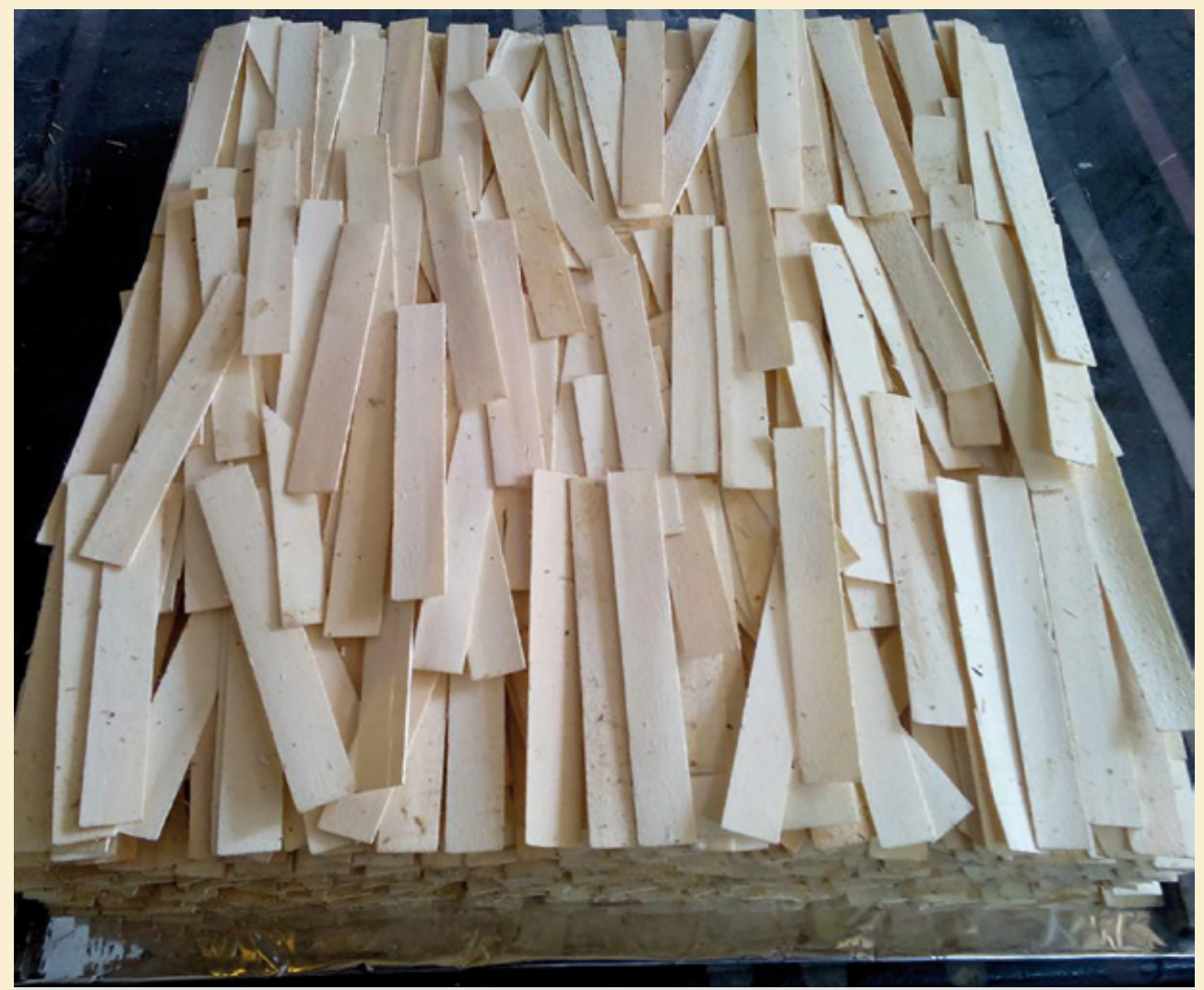

Photo 1.

Oriented strand lumbers (OSL) mat before being placed in the hot-press.

Photo H. R. Taghiyari. 


\section{RÉSUMÉ}

\section{EFFETS DU NANO-SILANE SUR LES PROPRIÉTÉS PHYSIQUES ET MÉCANIQUES DES PANNEAUX STRUCTURAUX ORIENTÉS (OSB)}

Cette étude s'est penchée sur les effets de la teneur en résine et en composés de nano-silane (NS) sur les panneaux structuraux orientés (OSB), un important produit en bois reconstitué. Des panneaux OSB ont été fabriqués avec de la résine d'urée-formaldéhyde (UF) à $8 \%$ et à $10 \%$ (sur poids sec des panneaux), avec application de NS à deux teneurs en fonction de la teneur en résine UF. Nos résultats montrent que les traitements aux deux teneurs différentes en résine donnent des valeurs très proches pour les modules de rupture et d'élasticité, la flexion au choc et la résistance à la traction. Cela indique que la compacité élevée des lamelles de la matrice OSB est le facteur déterminant des propriétés mécaniques globales des panneaux composites. L'interaction entre NS et résine UF affaiblit significativement ces propriétés dans la plupart des cas de traitement à $10 \%$ NS, alors que le dosage de NS à $20 \%$ est suffisant pour contribuer activement au processus de collage des lamelles et compense les pertes en partie. L'analyse par cluster indique que les propriétés mécaniques sont généralement davantage fonction de la compacité de la matrice composite que de la teneur en résine. Dès lors, l'étude conclut que le NS n'est pas à recommander à l'industrie en raison de ses effets négatifs sur la plupart des propriétés physiques et mécaniques des panneaux OSB.

Mots-clés : nanomatériaux, panneaux structuraux orientés (OSB), panneaux de particules, composé de silane, bois composite, Zycosil, Iran.

\section{ABSTRACT}

\section{EFFECTS OF NANO-SILANE ON THE PHYSICAL AND MECHANICAL PROPERTIES OF ORIENTED STRAND LUMBER (OSL)}

The effects of resin content and nano-silane (NS) compounds on oriented strand lumber (OSL), an important engineered wood product, were studied here. OSL panels were produced using two different urea-formaldehyde (UF) resin contents of $8 \%$ and $10 \%$, based on the dry weight of the wood strips; two NS contents were applied based on the UF resin content. Our results show that treatments with the two different resin contents produce very similar values for modulus of rupture (MOR), modulus of elasticity (MOE), impact bending (IB), and tensile strength (TS). This revealed that the high compactness of strips in the OSL matrix was the predominant factor determining the overall mechanical properties of the composite panels. The interaction between NS and UF-resin significantly reduced these properties with most treatments at $10 \%$ NS, while $20 \%$ NS was enough to contribute actively to the process of binding the strips together and compensated for part of the loss. Cluster analysis indicated that the mechanical properties were generally dependent on the compactness of the composite matrix rather than on the resin content. Based on these findings, the study concluded that NS is not to be recommended to the industry because of its negative effects on most physical and mechanical properties in OSL panels.

Keywords: nano-materials, oriented strand lumber (OSL), particleboard, silane compounds, wood-composite, zycosil , Iran.

\section{RESUMEN}

\section{EFECTOS DE LOS NANOSILANOS EN LAS PROPIEDADES FÍSICAS Y MECÁNICAS DE TABLEROS DE MACRO-VIRUTAS ORIENTADAS (OSL)}

Se estudiaron los efectos del contenido de resina y de compuestos de nanosilanos (NS) en los tableros de macro-virutas de madera orientadas (OSL), un importante producto de madera transformada. Se fabricaron tableros OSL con resina de urea formaldehído (UF) al $8 \%$ y al $10 \%$ (del peso seco de los tableros), aplicando dos contenidos de NS en función del contenido de resina UF. Nuestros resultados muestran que los tratamientos con los dos contenidos de resina arrojan valores muy similares en los módulos de ruptura y elasticidad, flexión dinámica y resistencia a la tracción. Esto indica que la alta compacidad de las astillas de la matriz OSL es el factor determinante de las propiedades mecánicas globales de los tableros compuestos. La interacción entre NS y resina UF reduce significativamente dichas propiedades en la mayoría de casos con tratamiento de NS al $10 \%$, mientras que con NS al $20 \%$ fue suficiente para contribuir activamente al proceso de encolado de las astillas y compensa en parte las pérdidas. El análisis de conglomerados indica que las propiedades mecánicas suelen depender más de la compacidad de la matriz compuesta que del contenido de resina. En base a esto, el estudio concluye que no es recomendable el uso de NS en la industria por sus efectos negativos en la mayor parte de propiedades físicas y mecánicas de tableros OSL.

Palabras clave: nanomateriales, tableros de macro-virutas de madera orientadas (OSL), tableros de partículas, compuesto de silano, madera compuesta, Zycosil, Irán. 


\section{Introduction}

Trees have a lot of advantages for people living in the surrounding habitat, including air filtration, beauty, financial benefits, etc. Fast-growing tree species can satisfy, to some extent, the ever-growing needs for wood. However, they produce light density wood with low mechanical properties, which are vulnerable to biological-deteriorating agents too (Hein et al., 2013; Maresi et al., 2013; Arce and Moya 2015; De Medeiros et al., 2016). Researchers are therefore trying to develop various types of engineered wood with improved properties to compensate for the above mentioned disadvantages (Mendez et al., 2013; Ozdemir and Tutus, 2013; De Almeida Andrade, 2016). The engineered wood products cover a wide range of materials from wood itself as well as wood derivatives, lignocellulosic materials, and wood composites (Liu et al., 2016; Meekum and Wanghheeree, 2016; Qian et al., 2016). Among the engineered wood, oriented strand boards and lumbers (OSB and OSL) are important and widely studied around the word (Zhang and Smith, 2010; Akrami, 2014; Candan and Akbulut, 2014). Different wood species have so far been studied to produce strong and cheap OSB and OSL panels with high quality, among which Scot pine, spruce, rubberwood, and poplar can be mentioned (Malanit et al., 2005; Akrami, 2014).

In recent two decades, nanotechnology was used to improve quality and eliminate disadvantages in many materials (Poda et al., 2013; Saber et al., 2013), though unusual changes may occur in the properties of materials when the size range is reduced to nanometer scale (Li, 2012). Different nanomaterials were used to improve fire resistance, biological resistance, water repellency, and mechanical properties in many solid wood species and wood-composite materials (Palanti et al., 2012; Salari et al., 2013; Taghiyari, 2014). Silane compounds were reported to have water repellency; they were reported to improve some properties in wood-composites (Taghiyari, 2013; Taghiyari et al., 2015). However, this organic nanomaterial was not tested in OSB or OSL panels. As urea-formaldehyde (UF) resin is very popular in composite-manufacturing factories in Iran and no other composite panel is produced at industrial scale, the present research project aimed at studying the effects of addition of nano-silane to OSL panels with UF resin on the physical and mechanical properties.

\section{Materials and methods}

\section{Specimen preparation}

Poplar trees of 15 years of age were cut from Khoy city (Azarbayjan Sharghi Province, Iran). Density of the poplar wood was $0.42 \mathrm{~g} / \mathrm{cm}^{3}$. Poplar logs were first peeled. Before stripping the veneers, they were dried to a moisture content of $6 \%$. The strips were $150 \mathrm{~mm} \times 20 \mathrm{~mm} \times 1 \mathrm{~mm}$ in dimension with the length of the strips being aligned in the longitudinal direction of poplar logs. They were dried for 48 hours at $50^{\circ} \mathrm{C}$ and then kept in plastic bags. Urea-formaldehyde resin (UF), with 200-400 cP in viscosity, 47 seconds of gel time, and $1.277 \mathrm{~g} / \mathrm{cm}^{3}$ in density was purchased from Iran Choob Co. (Ghazvin, Iran); the UF resin contained $62 \%$ solids. As a hardener, $2 \%$ ammonium chloride was used. OSL panels with two resin contents of $8 \%$ and $10 \%$ were produced. The mixed resin and hardener was sprayed on the strips in a rotary drum. Once sprayed, the strips were manually arranged in a forming to be hot-pressed for $10 \mathrm{~min}$ at $170^{\circ} \mathrm{C}$. All panels were produced with the target density of $0.7 \mathrm{~g} / \mathrm{cm}^{3}$; that is, more than $66 \%$ increase in comparison to the raw material. Final thickness of panels was $16 \mathrm{~mm}$. Five replicate OSL panels were produced for each treatment, 30 panels altogether. Panels were kept in a conditioning room $\left(30^{\circ} \mathrm{C}\right.$, and $45 \pm 2 \%$ Relative Humidity) for a month.

\section{Nano-Silane application}

Organo-silane reacted with organic reactant to produce liquid nano-silane (NS) at nano scale. The NS produced had a size range of 30 to $80 \mathrm{~nm}$. The color of the nano suspension was pale yellow, the flash point was more than $85^{\circ} \mathrm{C}$, specific gravity of $1.05 \mathrm{~g} / \mathrm{mL}$ (at $25^{\circ} \mathrm{C}$ ), and viscosity of 500-1,000 cps (at $25^{\circ} \mathrm{C}$ ). Using a magnetic stirrer, the nano suspension was mixed for 30 min with urea-formaldehyed resin (US) before being smoothly sprayed on the strips in a rotating drum. Two NS-contents of $10 \%$ and $20 \%$ (based on the resin content) were chosen based on previous studies on other wood-composite panels (Taghiyari, 2013; Taghiyari et al., 2015).

\section{Physical and mechanical tests}

Specimen preparation and tests were conducted according to the specifications in American Society of the International Association for Testing and Materials (ASTM) and European norm (EN) standards: ASTM D-4761 for modulus of rupture (MOR), modulus of elasticity (MOE), and internal bond (IB) tests, ASTM D-1037 for tension parallel to grain, ASTM D-143 for shear strength parallel to grain, and EN-317 for WA and TS. All specimens were uniformly dried to $7.5 \%$ moisture content before the tests were carried out in order to unify the thermo-hygromechanical behavior of wood that affects the results of the tests (Figueroa et al., 2012). Compaction ratio was calculated based on mat density to wood density. As the compaction ratio increased, the gaps among the particles and strips in wood composites decreased.

\section{Statistical analysis}

SAS software program (version 9.2, 2010) was used to conduct two-way analyses of variance (ANOVA) to discern significant difference among different treatments at the 95\% level of confidence. Grouping of similar treatments was made by Duncan's multiple range test. Hierarchical cluster analysis with Ward's method was performed using SPSS/20 (2012) to clarify similarities and dissimilarities among different treatments based on more than one property at the same time. In this analysis, the scaled indicator determines how much the treatments are similar or different. Fitted-line and scatter plots were made using Minitab software, version 16.2.2 (2010). 


\section{Results and discussion}

The highest MOR value was found in the two control panels without any NS-contents (figure 1); no statistically significant difference was found between the two control values. Compaction ratio of OSL panels was calculated to be 1.67; this indicated that although resin content can be considered one of the main factors in improvement of MOR as a mechanical property, in OSL lumbers and when the density was nearly twice the original wood strips the OSL panels were made of, the compactness of the strips played more importantly than resin content. This rule was applicable for NS-treated lumbers too; that is, panels with the same NS-content but different resin content of $8 \%$ and $10 \%$ showed nearly the same MOR values (figure 1).

Addition of NS to the mat at both $10 \%$ and $20 \%$ contents significantly reduced MOR (figure 1). Previously, it was reported that the addition of NS improved physical and mechanical properties in medium-density fiberboards (MDF) (Taghiyari et al., 2015); silane compound also increased integrity among fibers in MDF matrix and significantly reduced air and liquid permeability (Taghiyari, 2013). The specific surface area of fibers used in the production of MDF panels is quite higher than those of the strips used in OSL panels. It is hypothesized that the higher surface contact among fibers in MDF resulted in significant improvement in properties in MDF. This, however, cannot be generalized in all wood composites, as it is the case in OSL panels in which addition of NS to panels decreased MOR. Further studies should be carried out to finalize the reasons of decrease in properties in OSL panels. Comparison among the NS-treated panels showed no decrease in NS20\% panels compared with the NW10\% panels; in fact, NW20\% panels with $8 \%$ resin content had higher MOR than their counterpart with $10 \%$ NW. This was because in the higher NS-content of $20 \%$, NS was enough to actively participate in the process of sticking the strips in the composite matrix, improving the property. A former study reported improvement in medium-density fiberboard (MDF) as a result of addition of nano-silane (Taghiyari et al., 2015).

MOE values too showed no significant difference between panels produced with the two resin contents of $8 \%$ and $10 \%$ (figure 1). This confirmed that OSL panels with higher compaction ratio are more dependent on the compactness, and the final density of the composite panel, than they are on the resin content within a particular range of resin content. Addition of NS to panels improved MOE values at both UF-resin contents. Moreover, the two NS contents showed no difference between them in either of the resin contents, again proving the higher impact of density and compactness of strips than that of the resin content in OSL panels.

The highest and lowest impact bending values were found in R10\%-NS20 (76.2 $\mathrm{MPa})$ and control (64.7 MPa) panels, respectively (figure 2). Panels with the same NS contents but different resin contents showed nearly the same IB values, again proving that compactness was more influential on impact bending than resin content. Addition of NS improved impact bending, though not statistically significant. As to the IB values, increase in resin content from $8 \%$ to $10 \%$ improved IB in all treatments, though not statistically significant in all cases (figure 2). Addition of $10 \%$ of NS on the strips decreased IB values in both resin contents; however, addition of $20 \%$ of NS drastically decreased the values. This showed that contrary to the mechanical properties studied so far, IB was more dependent on resin content rather than the compactness of strips in the composite matrix.

Increase in resin content improved both shear and tension strenghs parallel to grain (figure 3), while addition of NS significantly reduced both of these two
Figure 1.

Modulus of rupture (MOR) and modulus of elasticity (MOE) values in the six oriented strand lumbers (OSL) panels produced (NS=nano-silane content). 
strengths. The significant decrease in the properties as a result of addition of NS indicated the negative interaction between NS and UF-resin in the matrix.

TS calculations showed that the values were nearly the same with no significant difference between the counterpart treatments with resin contents of either $8 \%$ or $10 \%$ (figure 4 ). This indicated again the higher impact of compactness on thickness swelling than resin content, similar to some of the mechanical properties discussed earlier. Addition of NS to the composite drastically increased TS values. This revealed the negative interaction between NS and UF-resin in OSL matrix, though NS was reported to improve TS and decrease liquid permeability in another wood-composite material (MDF) (Taghiyari, 2013; Taghiyari et al., 2015). Water absorption (WA) values did not show any particular trend; lack of a steady trend was as a result of the interaction between NS and UF-resin.

Results of the present study showed that the interaction of the two important factors of compactness and resin content in the OSL composites played interchangeably for different physical and mechanical properties. For MOR, MOE, IB and TS, compactness played more importantly, while both compactness and resin content interactively affected IB, shear and tension strengths parallel to grain. Moreover, addition of nano-silane to OSL panels reacted differently for different properties, showing that the interaction of NS versus UF-resin did not always have the same increasing or decreasing effect on all properties.

Cluster analysis of the six OSL treatments clearly showed distinct different clustering of the two control treatments with resin contents of $8 \%$ and $10 \%$ from the other four NS-containing treatments (figure $5 \mathrm{a}$ ). Moreover, the other four treatments with NS-contents were closely clustered based on their NS contents rather than resin contents. This indicated that the overall mechanical properties of OSL panels were more related to the density and compactness of the composite panels than they were to their resin contents, within the particular resin contents of $8-10 \%$. Cluster analysis of the six treatments based on the physical properties revealed similar distinct clustering of the two control treatments versus the other four NS-contained ones as it was observed in the mechanical cluster (figure 5b); however, there are two points in this regard. Firstly, the control specimens did not show much similarity as in the cluster analysis based on the mechanical properties, indicating the higher impact of resin on the physical properties. Secondly, the four NS-contained treatments did not show distinct clustering among the treatments based on a clear trend, showing the interaction between water repellent property of nano-silane compounds used in them versus resin content. 
54 BOIS ET FORETS DES TROPIQUES, 2016, N³30 (4)

FOCUS / NANO-SILANE IN ORIENTED STRAND LUMBER

Tension parallel to grain ( $\mathrm{MPa})$

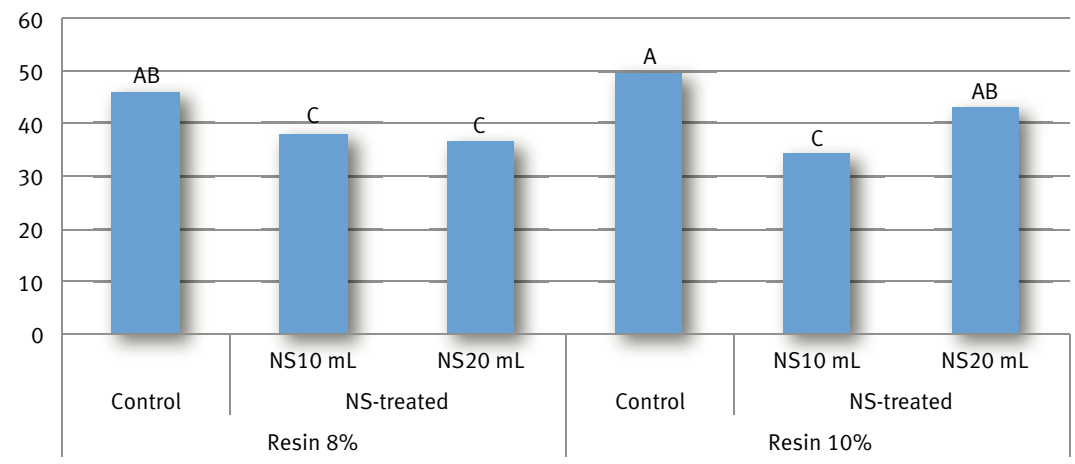

Shear strength parallel to grain (MPa)

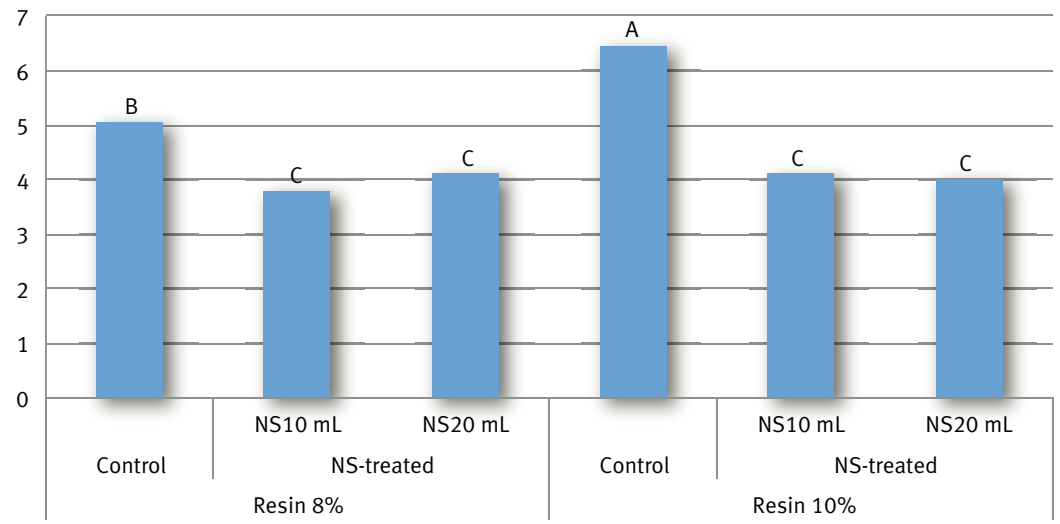

Figure 3.

Shear and tension strengths parallel to grain in the six oriented strand lumbers $(\mathrm{OSL})$ panels produced $(\mathrm{NS}=$ nanosilane content).
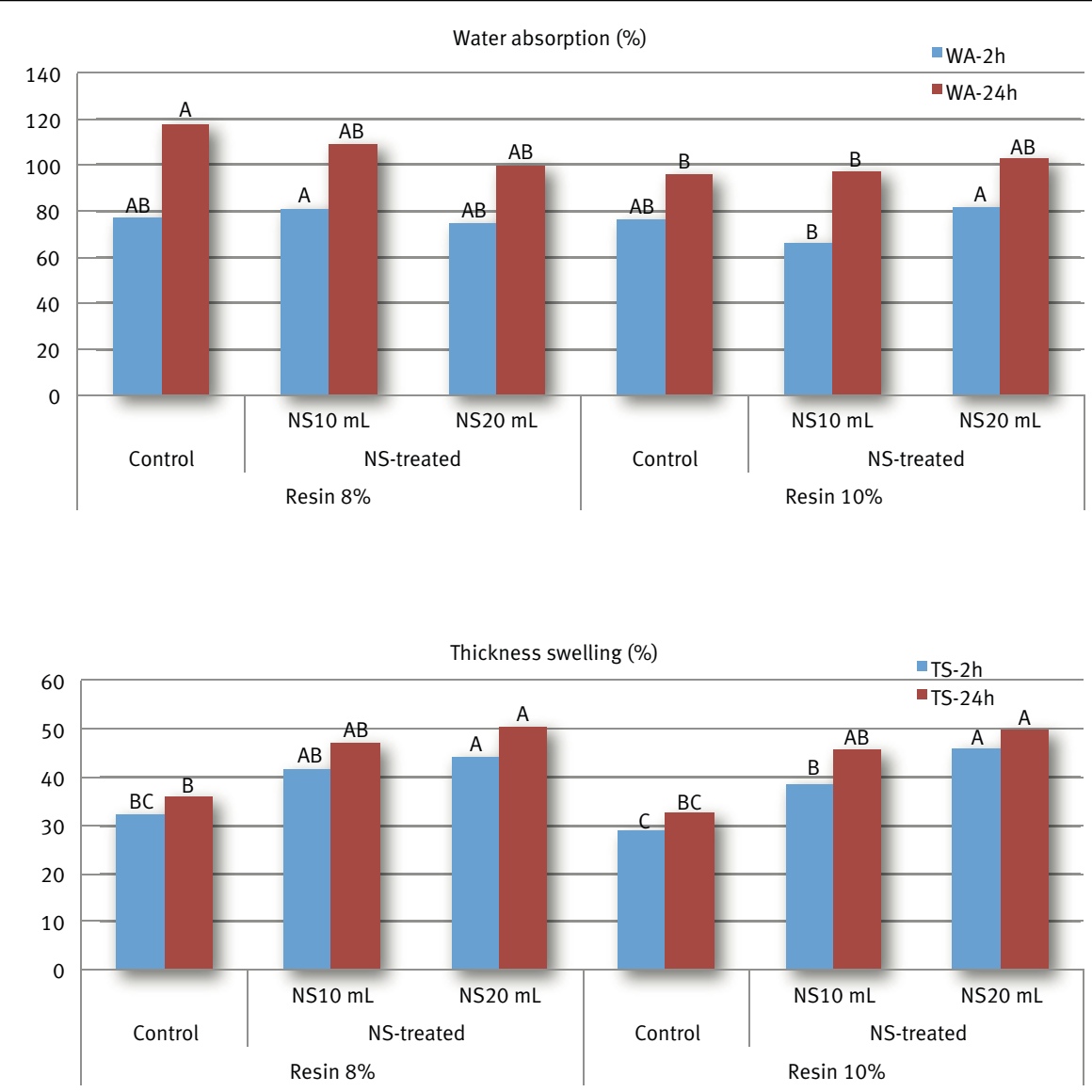

Figure 4.

Water absorption and thickness

swelling values in the six oriented strand lumbers $(\mathrm{OSL})$ panels produced (NS=nano-silane content). 


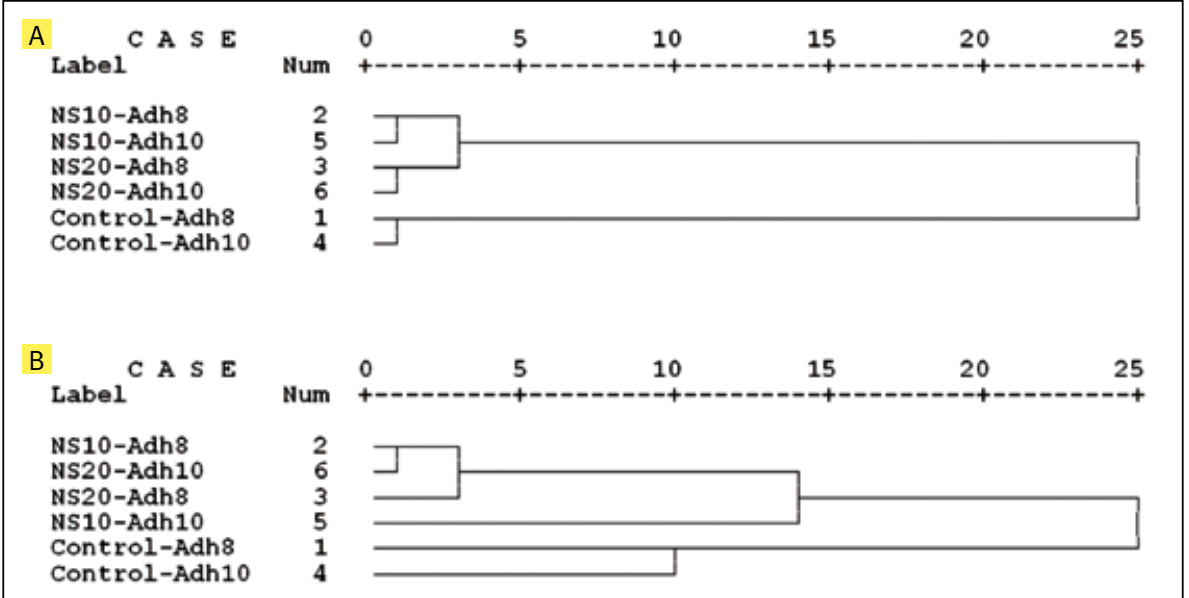

Figure 5.

Cluster analysis of the six oriented strand lumbers (OSL)

panels produced based on the mechanical $(A)$ and physical

(B) properties (Adh=resin content; NS=nano-silane content).

Li D., 2012. Nanostructuring materials towards conventionally unachievable combination of desired properties. Journal of Nanomaterials and Molecular Nanotechnology, 1(1). dx.doi. org/10.4172/2324-8777.1000e102

Liu X., Smith G. D., Jiang Z., Bock M. C. D., Boeck F., Frith O., Gatoo A., Liu K., Mulligan H., Semple K. E., Sharma B., Ramage M., 2016. Nomenclature for engineered bamboo. BioResources, 11 (3): 1141-1161.

Malanit P., Kyokong B., Laemsak N., 2005. Oriented strand lumber from rubberwood residues. Walailak Journal of Science and Technology, 2 (2): 115-125.

Maresi G., Oliveira Longa C. M., Turchetti T., 2013. Brown rot on nuts of Castanea sativa Mill: An emerging disease and its causal agent. iForest 6: 294-301. doi: 10.3832/ifor0952-006

Meekum U., Wangkheeree W., 2016.

\section{Acknowledgements}

The present research project was financed by Shahid Rajaee Teacher Training University for which we are grateful. The authors appreciate constant scientific support of Prof. Olaf Schmidt (The University of Hamburg, Germany).

\section{REFERENCES}

Akrami A., 2014. Development and characterization of oriented strand boards made from the European hardwood species: beech (Fagus sylvatica L.) and poplar (Populus tremula L.). A thesis submitted in partial fulfillment of the requirements for the degree of Doctor of Natural Science, Faculty of Mathematics, Infornmatics, and Natural Sciences, University of Hamburg, 169 p.

Arce N., Moya R., 2015. Wood characterization of adult clones of Tectona grandis growing in Costa Rica. CERNE, 21(3): 353-362.

Candan Z., Akbulut T., 2014. Nano-engineered plywood panels: Performance properties. Composites, Part B, 64: 15-161.

De Almeida Andrade A. C., Da Silva J. R. M., Braga Junior R. A., Moulin J. C., 2016. Distinction of mechanically processed wood surfaces with similar qualities using sunset laser technique. CERNE, 22 (2): 159-162.

De Medeiros F. C. M., Gouveia F. N., Bizzo H. R., Vieira R. F., Del Menezzi C. H. S., 2016. Fungicide activity of essential oils from Brazilian Cerrado specie against wood decay fungi. International Biodeterioration and Biodegradation, 114: 87-93.

Figueroa M., Bustos C., Dechent P., Reyes L., Cloutier A., Giuliano M., 2012. Analysis of rheological and thermo-hygro-mechanical behaviour of stress-laminated timber bridge deck in variable environmental conditions. Maderas, Ciencia y Tecnologia, 14: 303-319.

Hein P. R. G., Silva J. R. M., Brancheriau L., 2013. Correlations among microfibril angle, density, modulus of elasticity, modulus of rupture and shrinkage in 16-year-old Eucalyptus urophylla $\times E$. grandis. Maderas, Ciencia y Tecnologia, 15: 171-182.
Manufacturing of lightweight sandwich structure engineered wood reinforced with fiber glass: Selection of core materials using hybridized natural/engineered fibers. BioResources, 11 (3): 7608-7623.

Mendez R. F., Junior G. B., De Almeida N. F., Surdi P. G., Barberiro I. N., 2013. Effects of thermal pre-treatment and variables of production on properties of OSB panels of Pinus taeda. Maderas, Ciencia y Tecnologia, 15 (2): 141-152.

Qian Y., Otsuka Y., Sonoki T., Mukhopadhyay B., Nakamura M., Jellison J., Goodell B., 2016. Engineered microbial production of 2-pyrone-4,6-dicarboxylic acid from lignin residues for use as an industrial platform chemical. BioResources, 11 (3): 6097-6109.

Ozdemir F., Tutus A., 2013. The effects of some fire retardants on physical and mechanical properties of HDF panels covered with resin-impregnated paper. Lignocellulose, 2 (2): 329-337.

Palanti S., Feci E., Predieri G., Francesca V., 2012. Copper complexes grafted to amino-functionalized silica gel as wood preservatives against fungal decay: Mini-blocks and standard test. BioResources, 7: 5611-5621.

Poda A. R., Moser R. D., Duddy M. F., Doorenbos Z., Lafferty B. J., Weiss Jr. C. A., et al., 2013. Nano-aluminum thermite formulations: Characterizing the fate properties of a nanotechnology during use. Journal of Nanomaterials and Molecular Nanotechnology, 2: 1. dx.doi.org/10.4172/2324-8777.1000105

Saber R., Shakoori Z., Sarkar S., Tavoosidana Gh., Kharrazi Sh., Gill P., 2013. Spectroscopic and microscopic analyses of rodshaped gold nanoparticles interacting with single-stranded DNA oligonucleotides. IET Nanobiotechnology, 7: 42-49.

Salari A., Tabarsa T., Khazaeian A., Saraeian A., 2013. Improving some of applied properties of oriented strand board (OSB) made from underutilized low quality Paulownia (Paulownia fortunie) wood employing nano-SiO, Industrial Crops and Products, 42: 1-9.

Taghiyari H. R., 2013. Nano-zycosil in MDF: gas and liquid permeability. European Journal of Wood and Wood Products, 71 (3): 353-360. doi:10.1007/s00107-013-0691-6

Taghiyari H. R., 2014. Nanotechnology in Wood and Wood-Composite Materials. Journal of Nanomaterials and Molecular Nanotechnology, 3 :1. dx.doi.org/10.4172/2324-8777.1000e106

Taghiyari H. R., Karimi A., Tahir P. Md., 2015. Organo-silane compounds in medium density fiberboard: physical and mechanical properties. Journal of Forestry Research, 26 (2): 495-500.

Zhang C., Smith G. D., 2010. Effects of nanoclay addition to phenolformaldehyde resin on the permeability of oriented strand lumber. Wood and Fiber Science, 42 (2): 553-555. 